\title{
Political posters, the Soviet Enlightenment and the construction of a learning society, 1917-1928
}

\author{
Elena Ignatovich \\ University of British Columbia, Canada (lena.ignatovich@ubc.ca) \\ Pierre Walter \\ University of British Columbia, Canada (pierre.walter@ubc.ca)
}

\begin{abstract}
This paper explores the construction of a Soviet learning society represented in Soviet political posters during the first decade after the 1917 Socialist Revolution. The theoretical framework is based on studies of learning societies, lifelong education and learning, Soviet education, and the theory of multiple modernities. We employed a poststructuralist discourse analysis that allowed us to explore verbal and non-verbal poster elements to identify key domains in the construction of the Soviet learning society. Our study identified six main discursive visual and textual messages in political posters as educational devices in the development of the Socialist learning society. Findings show that learning was embedded in broader social, political, economic and cultural practices and took multiple forms. Political posters were motivators for learning, learning devices, means to communicate the Soviet party-state agenda, and part of the social-political and cultural curriculum of the learning society to come. Our study makes a contribution to scholarship on learning societies as these are constructed in socialist as well as capitalist societies.
\end{abstract}

Keywords: Adult learning and education, new Soviet Enlightenment, political posters, Soviet learning society

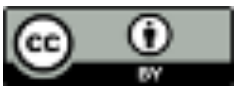




\section{Introduction}

Despite numerous studies in the field of learning/ educative/ knowledge societies, there is little knowledge about the practices of developing a learning society in the Soviet Union, which in fact began to develop such a society after the October Socialist Revolution of 1917. The Soviet period from 1917 to 1928 (1930) is recognised as the Cultural Revolution in the state and 'romanticism and experimentalism' in education (Brickman \& Zepper, 1992, p. 30), and can be seen as one of the most exciting pages in the history of European adult education. In a surprisingly short period, the Soviet Union managed to construct a new socio-economic and political space that had never been put into practice before and which fostered a new type of egalitarian society. The building of a new socialistic reality required from all Soviet citizens a new way of thinking that could only be achieved by mobilising mass education and learning by both children and adults in formal and informal settings.

A vast body of literature has looked into the Soviet formal education of children, adult literacy education, films, visual art, book and newspaper publishing, and the formal education of adults (e.g., Eklof, 2008; Fitzpatrick, 1970, 1979; Kenez, 1985). However, no research has been done on how the Soviet state constructed a Soviet learning society during the early years of the Soviet Revolution and the formation, defence, and consideration of the new socialist state in first decade, 1917-1928. This was still a time of relative pluralism for the Bolshevik party-state when it was searching for new forms of adult education for the Soviet people. It was a transition period from the past into the future, involving many critical historical events: the October (Bolshevik) Revolution (1917), the Civil War and defense of the Bolshevik state (1918-20), state capitalism under Lenin and the New Economic Plan (1921-1928), and the formation of the Union of Soviet Socialist Republics (1922). These were all before the advent of a more centralised, rigid party-state under Stalin, and the first Five-Year Plan (1928) regulating, systematising, and accelerating collectivisation and industrialisation.

Several types of Soviet 1917-1920s era posters have been studied to date, but none focus on posters for adult education. Oushakine (2016), for example, examines how the ideas of Communism were represented in children's books and posters; Dobrenko (2009) looks at how 'the enemy' as 'Other' was constructed in Bolshevik political posters; Williams (2012) analyses health posters designed to mobilise the masses against chronic alcoholism; Starks (2017) examines how Soviet health authorities used posters to promote health care innovations and 'sanitary enlightenment' to the public; still other researchers have studied the broad historical sweep of posters as public education in the Soviet Union (Bonnell, 1999; White, 1988). This paper explores the role of posters related to adult learning or education during the establishment of a Soviet educative state during the first decade following the October Revolution. In the sections which follow, we provide a theoretical framework, study methodology, an analysis of key posters (findings), a discussion which includes the development of a conceptual model, and a conclusion.

\section{Theoretical framework}

Our research is grounded in four theoretical and research traditions: (a) theories, policies and practices related to lifelong learning and learning societies; (b) the theory of multiple modernities, which argues that learning societies can be constructed in socialist as well as capitalist societies; (c) the historical context and theories of education in the Soviet 
Union 1917-1920s; and (d) theory related to how political posters communicate and educate in the public sphere (Ginsberg, 2013; Roselle, 2017).

\section{Learning societies}

Our study is informed by broad scholarship on the theories, policies and practices of learning societies/ educative societies/ knowledge societies and states (cf. Coffield, 2000; Jarvis, 2007; Schugurensky, 2007). These concepts emerged in the 1940s to reflect the state's role (mainly in liberal Western democracies) in promoting systems of nonformal adult education and self-directed, informal and lifelong learning to address the growing incapability of formal education systems to meet the demands made upon them, and in envisioning learning societies as alternative futures. Notably, we acknowledge critiques of the concept of learning societies as utopian and normative, as assuming a totalising, common humanity across difference, having multiple definitions and lacking clear criteria in its application (English \& Mayo, 2021; Schugurensky, 2007). Further, in our study, we recognise (but do not engage) contemporary debates about the 'knowledge society' as this concept relates to the knowledge economy, learning societies and lifelong learning (Livingstone \& Guile, 2012; Schugurensky, 2007). That is, we do not apply prevailing theoretical concepts of learning societies nor knowledge societies to our data, but instead derive a particularistic historical understanding of this concept as it was developed in Russian society in the 1920s. Moreover, although we appreciate the characterisation of the Soviet public sphere of the 1917-1920s as a 'proletarian public sphere' with 'revolutionary' public spaces (Hake, Glastra, \& Schedler, 2004), in this paper, we do not take this concept as central to our analysis of the educative role of Soviet posters in constructing learning society (but do see it as a valuable frame for future research on the topic). Finally, although we do not directly engage debates about adult learning in the public sphere; mainly as related to Habermas's (1962/1991) definition of the public sphere as a 'society engaged in critical public debate' (p.52), we implicitly take informal learning and nonformal education as occurring in a revolutionary and democratic public sphere, albeit shaped by the Soviet state, not by a Western liberal democratic state.

We use the terms 'learning society', 'knowledge society' and 'educative state' to characterise an historical, revolutionary Soviet state and society which put immense importance on lifelong, lifewide learning and adult education. This was a state which aimed to construct an entirely new society from the old Russian society; that is, it was a revolutionary 'educative state' furthering a utopian, egalitarian, lifewide and lifelong learning society.

\section{Multiple modernities}

We employ the theory of multiple modernities (cf. Arnason, 2010; Eisenstadt, 2000) which allows us to argue that a learning society might be constructed not only within a capitalist economy but also in socialist settings, in which the social and economic, individual, and collective, are constructed as a unity. Based on studies of modernising societies, this theory questions the very definition and characteristics of a modern society and provides evidence that a homogenising and hegemonic cultural-political program of social development does not exist. Thus, our study, in many respects, aims to challenge the notion of both capitalist societies and their 'learning societies' as totalising concepts. 
Instead, as noted above, we provide a particularistic, historical understanding of Soviet Russian from 1917 to the early 1920s.

\section{Historical context}

On the eve of the October Socialist Revolution-1917, the multinational, multilingual, and multireligious Russian Empire had a dominant Russian culture and Russian Orthodox Church (Harcave, 1970). Russia was an agrarian country with a developing segment of industrial production and a population of more than 125 million people (Waldron, 1997). Russian society was intensely patriarchal, with male husbands having almost unlimited power over women codified in law (Waldron, 1997, p. 69-70). The first and only census that was carried out in the Russian Empire in 1897 indicated that landed and landless peasants made up more than four-fifths of the population at $82 \%$, upper classes (royalty, nobility, higher clergy) comprised $12.5 \%$, working class (factory workers, artisans, soldiers, sailors), $4 \%$, and middle class (merchants, bureaucrats, professionals), $1.5 \%$ (M. Lynch n.d., cited in Bashqawi, 2019). Urban residents increased from 11\% in 1897 to 17\% in 1913 (Mironov, 2010).

The two social classes that offered their vision of a new world and led its construction in 1917 were primarily working class and middle-class professionals who represented less than 10\% of the population. The October Revolution of 1917 raised a question that had never been asked in the history of the humanity before: What does it mean to be a person of labour - a proletariat, labourer (truzhenik), worker - and to attempt to construct an egalitarian state of labourers, free of capitalism and fully managed by people of labour?

Among the first steps of the newly established state was increasing literacy levels among the population from 9 to 49 years old. In 1897, Russian literacy rates were only $29 \%$ among men and 13\% among women (Kahan, 1989, p. 244). To address low literacy, in December 1917, the Narkompros (People's Commissariat for Education) established an Out-of-School Department, one of the main tasks of which was the elimination of illiteracy in the country. On December 26, 1919, the decree On Liquidation of Illiteracy among the Population of RSFSR: Either Teach or Learn! was promulgated. The first schools for adult literacy and general education were created, and by 1928 , there were 1,400 such schools (Central Statistical Office, 1956, p. 222-223). During the same period, the number of technical colleges (technicums) increased from 295 to 1,037 and higher education institutions from 91 to 142 (Central Statistical Office, 1956, p. 227). Cultural enlightenment activities under the banner of the Out-of-School Department and the Proletkult (an organisation aimed at developing a new proletarian culture) operated widely in villages, and urban enterprises and workers' clubs promoted proletarian theatre, cinema, performative and visual arts, literature, and poetry (Fitzpatrick, 1970).

\section{Educative value of Soviet political posters}

Political posters are a type of communication and education (Roselle, 2017) which 'serve as vehicles of persuasion, instruction, damnation and social discourse in every communist nation' (Ginsberg, 2013, p. vii); as 'weapon(s) of mass indoctrination, a means of organising collective psychology’ (Polonsky, 1925, p. 14). Since the early 1920s, political posters have often been seen as propaganda and have a negative connotation in the West (Ginsberg, 2013). However, in societies that face a radical change in the social-political order, propaganda is a crucial part of education and political life; it motivates, supports, 
or reproves, reprograms attitudes and behaviour, and establishes social connections with the state or social class (Ginsberg, 2013). As Kenez (1985) argues, the Bolsheviks saw all propaganda, including books, films, and posters, as a part of education; as politprosvetrabota or political education work necessary to the formation of a new Soviet society.

From the start of the Soviet state in 1917, mass-produced posters played a vital role in the establishment of the new socio-economic, political, cultural order and the construction of a Soviet ideological discourse. They were cheap and quick to produce, expressive, concise, and straight-forward. Posters also continued the traditional design elements of Russian Orthodox religious icons commonly used in religious practice, thus allowing Russians a 'familiarity with a certain type of imagery and an assumption of its sacredness' (Bonnell, 1999, p. 4). Writing in the 1920s, Polonsky (1925), one of the first scholars studying Russian revolutionary posters, described a Soviet poster as follows (pp. 7-8):

\footnotetext{
... This is a poster. It screams from the fence, from the wall, from the window. It leaps brazenly into a passer-by's pupils. Whether the passer-by wants it or not, whether they are busy or not, whether they hurry or kill time - the poster draws attention to itself. With what? First of all, with the fire of coloured spots, a kind of flashy combination of colours. This feature defines the poster. Its task is to stand out of the series, to break forward from the mass of sheets, playbills, and ads, that plaster fences and walls. The poster must present at once what it wants, without extra explanation, without thinking. It is all in this blow - terse, yet witty, unadorned but impressive. Its text is as short as a scream.... All the features that the old poster lacked - the ideological vibrant, live connection with public interests, the inner significance that is able to excite the viewer - are the characteristics of the revolutionary poster... (It) focuses on the essential - it speaks about life and death, about struggle and victory, about violence and freedom, about bread and humanity, about the present and the future - about topics of broad, global significance.
}

The function of the posters was thus to catch the attention of passers-by, to reflect essential needs that matter here and now, to communicate a clear message from its first glimpse based on the simplicity of text and graphics. In a country with low literacy rates, posters were one way to communicate new ideology to those who could not read (Bonnell, 1999), and to offer them a new conceptual language - the language of revolution and drastic change.

Another important function of Soviet posters was to establish social and cultural normativity: to provide clear norms of behaviour, social values, and political beliefs to the population (Dosekin, 2015). This would then lead to the creation of a unified Soviet identity; of a Soviet person belonging to the working class, following Soviet life principles and patterns of behaviour and socialist morality (Danilova \& Nurieva, 2015). The posters created images of model citizens for generations of Soviet people and allow us to consider posters as a representation of everyday norms that were shared by the vast majority of Soviet citizens in the construction of the learning society.

\section{Methodology}

Although the literature on Soviet political posters is vast, none is explicitly dedicated to posters and the construction of the Soviet educative state. We employ Foucauldian poststructuralist discourse analysis (Nicoll, 2006; Rose, 2016) to investigate the key themes that posters related to learning or education 1917-1928 reveal in their relations to the 
historical context, and the political and social discourses of the time. Foucault's (1980) theory on discursive power construction through 'regimes of truth' significantly informed our study and provided a framework for analysing the selected posters. We consider each poster as a semiotic event comprising verbal and non-verbal texts (objects), constructing discourses, and engaging in them. In contrast to the structuralist view of discourse as a 'representation of reality' (Anderson \& Holloway, 2018, p. 200), we view discourse as 'a set of social practices ...that systematically form the objects of which they speak' (Foucault, 1977, p. 49), ways of constructing reality(-ies), knowledge production through language and practices (Foucault, 1978), socially produced and accepted 'true' forms of knowledge (Salter, 2014), meaning, and culture (Stevick, 2010); and as (an implicit) worldview (Stevick, 2010; Stewart, 2012). Following Foucault (1977, 1980), we see discourse as powerful in constituting reality, (re)creating the world, constructing, justifying, and shaping meaning and ways of thinking and the engagement of social actors. This study implies the deconstruction of the examined social practices constructed via posters to identify learning-related elements: knowledge, actors, objects, and interrelations among them. As such, we identified the 'regimes of truth' channelling the construction of a new world, the key actors and subjects allowed, how these are constructed via posters; that is, which teaching, learning and knowledge is allowed for public dissemination as 'truth' by the Soviet state.

As noted above, we roughly follow Brickman \& Zepper's (1992) periodisation of 1917-1930 as the period of 'Romanticism and experimentalism' in education. However, we have elected to end our analysis in 1928, before Stalin fully took over power in the USSR and before the first Five-Year Plan (1928) was instituted as a mechanism to systematically regulate collective efforts at constructing the new socialist state. The exact number of posters published in 1917-1928 is unknown. From spring 2017 to autumn 2020, Author 1 ran a series of queries in the Google.ru and Yandex.ru search engines resulting in numerous single postings of posters and their web collections located on both Russian and English segments of the Internet, e.g., The Soviet poster (https://tramvaiiskusstv. ru/plakat/o-kollektsii.html), The collection of Sergo Grigoryan (http://redavantgarde.com/), individual small collections on Pinterest and Etsy, as well as the Russian Posters Collection, 1919-1989, by Duke University (https://repository.duke.edu/dc/russianposters), to name a few. Queries were also run using text from the selected posters in Google.ru and Yandex.ru to find posters with similar themes. Our search resulted in over 150 adult education posters from 1917-1973, including 54 posters produced between 1919 and 1928.

Posters were selected based on the presence of non-verbal and/or verbal element(s) related to learning, education, enlightenment, schooling, knowledge, and books. In most cases, these elements were employed as institution-building devices related to education, book reading and adult learning. In our analysis, we selected 26 posters which refer to six general themes (Figure 1): The Enlightenment brought by the Revolution and its outcomes (4 posters), fighting illiteracy (reading) (2), reading as a social practice and motivation for reading (8), learning at any age (1), women liberated by literacy (8), and increasing cultural level (3). The posters also contain references to many other topics embedded in these larger discourses, including religion, science, new morality, socialist democracy, soviets (councils), and the army, to name a few. 
1. Glan-Globus, V. (n.d.). A woman-worker, be in the forefront of the builders of socialism. http://redavantgarde.com/

2. Isnar N.S. (1920). Woman, your literacy is the guarantee of your emancipation. Retrieved from Yandex.ru

3. Ivanov, S. (1920). A book is nothing but a man speaking in public. Retrieved from Yandex.ru

4. Kogout, N. (1921). From darkness to light. From battle to book. From grief to happiness. Retrieved from Yandex.ru

5. Kruglikova E. (1923). Woman! Learn to read and writel 'Oh, motherl If you were literate - you would have helped mel' Retrieved from Yandex.ru

6. Lavinskyi, (1927). A soldier of the Red Army, a book is your friend. Retrieved from Yandex.ru

7. Lekht, F. (1921). The emancipation of women workers is a duty of the women workers themselves. Retrieved from Yandex.ru

8. Makarychev, I., Raev, S. (1925). Every cook must learn to govern the state. Retrieved from Yandex.ru

9. Mogilevskyi, A. (1925). If books are not read, the letters soon forget. Retrieved from Yandex.ru

10. Moor, D. (1919). Royal regiments and the Red Army. Retrieved from Yandex.ru

11. Not a single illiterate by the tenth anniversary of the October Revolution. (n.d.). All illiterates [go to] the schools of illiteracy elimination. All literate [join] the society "Down with illiteracy." Retrieved from Yandex.ru

12. Organize reading houses (n.d.). Retrieved from Yandex.ru

13. Peasant woman be ready to leave the old life for the new one (n.d.). Retrieved from Yandex.ru

14. Pomanskyi, N. (1928). Instead of scolding and beating children, it is better to buy them a book. Retrieved from Yandex.ru

15. Radakov, A. (1920). An illiterate is a blind man. Failures and misfortunes await him everywhere. Retrieved from Yandex.ru

16. Radakov, A. (1920). Knowledge will break the chains of slavery. Retrieved from Yandex.ru

17. Simakov, I.V. (1921). Long live the sun and may the darkness disappear. Retrieved from Yandex.ru

18. Unknown artist (n.d.). The illiterate man stands outside of politics. First, he must be taught the alphabet. Retrieved from Yandex.ru

19. Unknown artist. (1920a). It is never too late to learn. School is open for everyone now. Welcomel Retrieved from Yandex.ru

20. Unknown artist. (1920b). The Day of Soviet propaganda. Knowledge - to all! Retrieved from Yandex.ru

21. Unknown artist. (1920c). What has the October Revolution given to a female worker and a peasant woman? Retrieved from Yandex.ru

22. Unknown artist. (1923). By the tenth anniversary of the proletarian revolution, the worker and the peasant must master $a$ book and a newspaper as a hammer and sickle. Krasnaya Novy publishing House. Retrieved from Yandex.ru

23. Unknown artist. (1925). Do you support the liquidation of illiteracy? Everyone into the society "Down with illiteracy". Lenin's covenants: No illiterate by the 10th anniversary of revolution." Retrieved from Yandex.ru

24. Unknown artist. (1927). Comradel After a hard day, go to the club, where you will get rest, knowledge and entertainment. Retrieved from Yandex.ru

25. Valerianov, N. (1925). Female workers and peasants, all to the elections. Retrieved from https://library.duke.edu

26. Zhelenskyi A. (1920). To possess more, one needs to produce more. To produce more, one needs to know more. Retrieved from Yandex.ru

Figure 1. Posters Analysed for the Study (cited in findings by author, date)

Since posters grab, fix, expose a specific social-political-cultural-economic historical moment (Ginsberg, 2013), we understand them as alternative visual 'texts' to the traditional analysis of written documents common in scholarly histories of the Soviet educative state. In the next section we present our findings, using a representative selection of 7 of the 26 posters in our analysis. All Russian poster texts were translated into English by Author 1. We understand, as a limitation of our study, that we are analysing posters as discursive texts widely promulgated ('supplied,' as it were) to the Soviet public at the time, and do not in fact know how the educational messages of posters were taken up, understood, or debated by the public as mass adult education. Instead, we focus on analysing the posters as a both a medium of Soviet mass education, and a 'curriculum' for the construction of the early Soviet learning state. 


\section{Findings}

Our findings illustrate six main discursive visual and textual messages of political posters as educational devices in the construction of the Socialist learning state. We present posters below only from the early years of political ferment shortly after the October Revolution (1917), mostly during the Civil War (1918-1920), and prefacing state capitalism under the New Economic Plan (1921-1928). These early years were a time of creative, pluralistic revolutionary fervour and defence of the new revolutionary state against the Tsarist old guard trying to overthrow it. Posters from these early years capture the euphoric birth of the new Bolshevik socialist state under Lenin, its vision for the future of humanity, and the role of adult learning and education with it. We would also argue that the themes of these early posters carry through Soviet state political posters and other forms of education (e.g., literacy campaigns) up through and after 1928. However, under Stalin, the Bolshevik revolution and adult education begin to be centralised, institutionalised, and regulated by a less pluralistic state. Additional educational themes then appeared in posters promoting the rapid collectivisation of agriculture and industrialisation under a more rigid command-state economy.

Findings below present posters which first reflect back on the 'old world' of Tsarist Russia as a counterpoint to posters envisioning a new socialist world. These two sets of posters portray the Bolshevik struggle against a Tsarist past of oppression, slavery, imperialism, exploitation, and patriarchy, and imagine a new utopian Socialist worker's learning society for the future. In the next sets of posters, we then learn how such a new world of a Soviet learning society is to be constructed, the educative, social spaces where this learning occurs, who will construct and disseminate what knowledge, and who will educate others about this new knowledge in and of the Soviet learning society. Additional posters analysed but not pictured in Figures 2-6 below are cited using the author and dates from 1919-1928 for poster sources and listed in the references. More recent citation dates in the section below are to academic references.

\section{Reflection on the old world}

Part of the learning process in Bolshevik society was a reflection on the Tsarist past. The 'Old World' is presented on a number of posters whose main function is to show what societal elements get rejected and need reconstruction.

Political powers of the Empire. At the top of the left-hand poster (Figure 2), the Old World appears as the place where the tsar and tsarina, circled by their (all male) police forces, priests, generals, bankers, and Rasputin (a mystic and healer for Prince Alexei, Nicholas II's son). A priest shouts and raises his hands to God; a foolish general dances and joyfully shouts out orders. The rest of the circle idly regard the backs of exhausted, disheartened and poorly shod peasant soldiers fresh from the front, some barefoot or wearing bast shoes (traditional peasant footwear). The tsar's rule is pictured as a time of death represented by the skull orb in the tsar's hands, gallows, and a dead soldier at the front of the poster. The poster identifies the powers that support and back up the unjust tsarist's rule: religion in the priest exalting in blessing and prayer, other lesser priests obsequiously regarding the reigning couple from the left. Another power (lined up to the right of the tsar) is the policing forces, presumably the Black Hundreds (monarchist, ultranationalists reactionaries), with whips and daggers in their hands. An overweight banker representing the capitalist forces of the Empire, is sitting at the foot of the tsarist throne lounging on sacks of money and smoking a cigar. To strengthen the message, the groups on the top are labelled with the following words: parasitism, hypocrisy, mockery, slavery, 
imperialism, violence, and exploitation. In the second picture, the throne and its surrounding sycophants are removed, and the viewer can clearly see what the tsarist regime was blocking common people from - in the background, there are multiple-storey buildings with the titles Arts, Freedom, Free from Exploitation Labour, Bread, and Science.

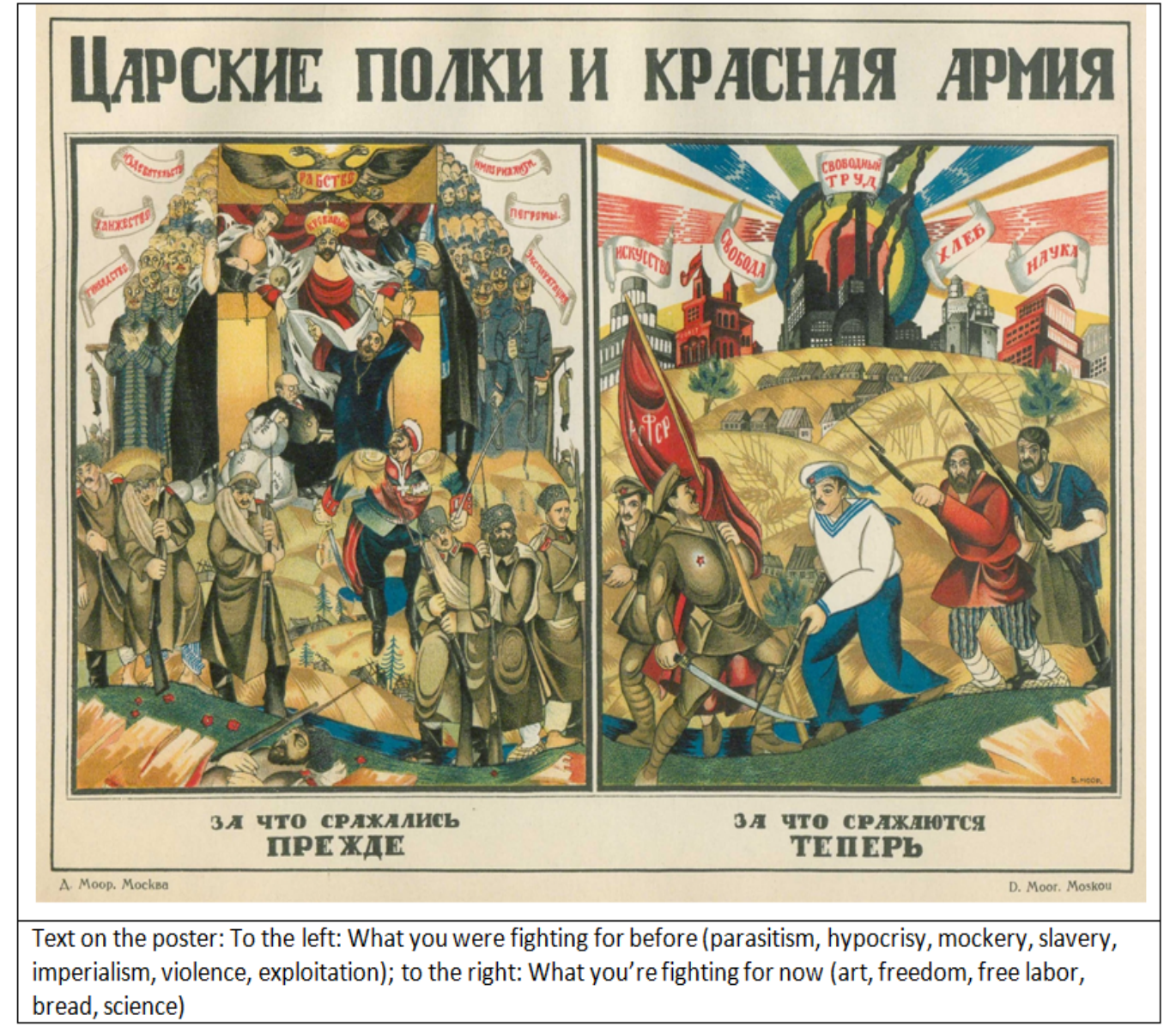

Figure 2. Royal Regiments and the Red Army. (Moor, 1919).

The power of religion represented in Figure 2 above, is also captured in other posters. One, for example, contains pictures of two greedy priests - one holding a book with the text 'Come to me every burdened labourer, and I will avoid you,' and another with a child in a baptismal font signed 'I am baptising the servant of God to replenish my wallet.' Religion is presented as an enterprise; religiousness is interpreted as the combination of ignorance of the common people and manipulations of the clergy. Priests are equated to traditional healers who also keep common people from knowledge and exploit their ignorance. Another poster pictures a sorceress in the Old World who ignorantly treats illnesses with anti-scientific techniques (Peasant woman be ready...,' $n / d$ ). Both religion and healing are seen as means of exploitation, and therefore, 'wrong' sources of knowledge.

Family life. A further poster depicts the positioning of a woman in a family hierarchy with her kitchen slavery as the sign of the old life that one needs to overcome. Another poster quotes a tsarist law legalising traditional patriarchy and the subordination of women. Other posters contain pictures of male violence against wives and children, heavy female household duties, non-stop childbearing, with a house seen as a prison for women ('Peasant woman be ready...,' n/d; Arshinov, 1923) 
The Old World is pictured as a place of darkness, struggle, and grief; the New World as an enlightened and liberated. 'Off the old life and the chains!' - shout posters proposing anti-war, -religion, -patriarchy, -exploitation, -capitalism, -violence, -oppression; a new version of the Soviet Enlightenment embraces all elements of life: family relations, household work, children upbringing, employment, and leisure (Kogout, 1921; Simakov, 1921).

\section{Envisioning the new world}

Although $79 \%$ of the Russian population on the eve of the 1917 Revolution lived in rural areas (Mironov, 2010), the posters present the New World as an industrial city with working factories, bridges, power lines, multiple-storey buildings, and palaces with names like: Free from Exploitation Labour, Science, Art (Kogout, 1921, Moor, 1919), Bread and Freedom (Moor, 1919). Science, Art and Labour appear as the main pillars of the new society, guaranteed to support the building of socialism. Posters picture the New World wholly owned and governed by people of physical labour (truzhenik), in which both men and women have equal rights to all resources and governing (Unknown artist, 1920c; Leht, 1921). The state is run by peasants' and workers' deputies (Unknown artist, 1920c), all decisions are openly made by gathering the majority of votes ('Peasant woman be ready...,' n/d), where Lenin proclaims 'every female cook' has learned 'how to govern the state' (Makarychev \& Raev, 1925).

A common symbol of new life in the New World used in the posters is the shining sun (Figure 3). Contrasting with the darkness, the sun represents the idea of a clear vision, the ability to see and understand, to be conscious. An endless crowd of common people in peasant clothing - the men with distinctive peasant haircuts and beards, women with braids, coloured smocks, and babushka head scarves - is standing together on a wide road facing the sunrise with their eyes on the opened books and newspapers in their hands. The scene resembles a church service; however, instead of being orchestrated by lines from the scripture or other sacred text as at mass and prayer, people are reading newspapers and various books individually, yet are all together in the same space and time. The poster presents adult learning as a collective process leading to a new life, with an individual contribution, but done collectively, with collective goals and outcomes. 


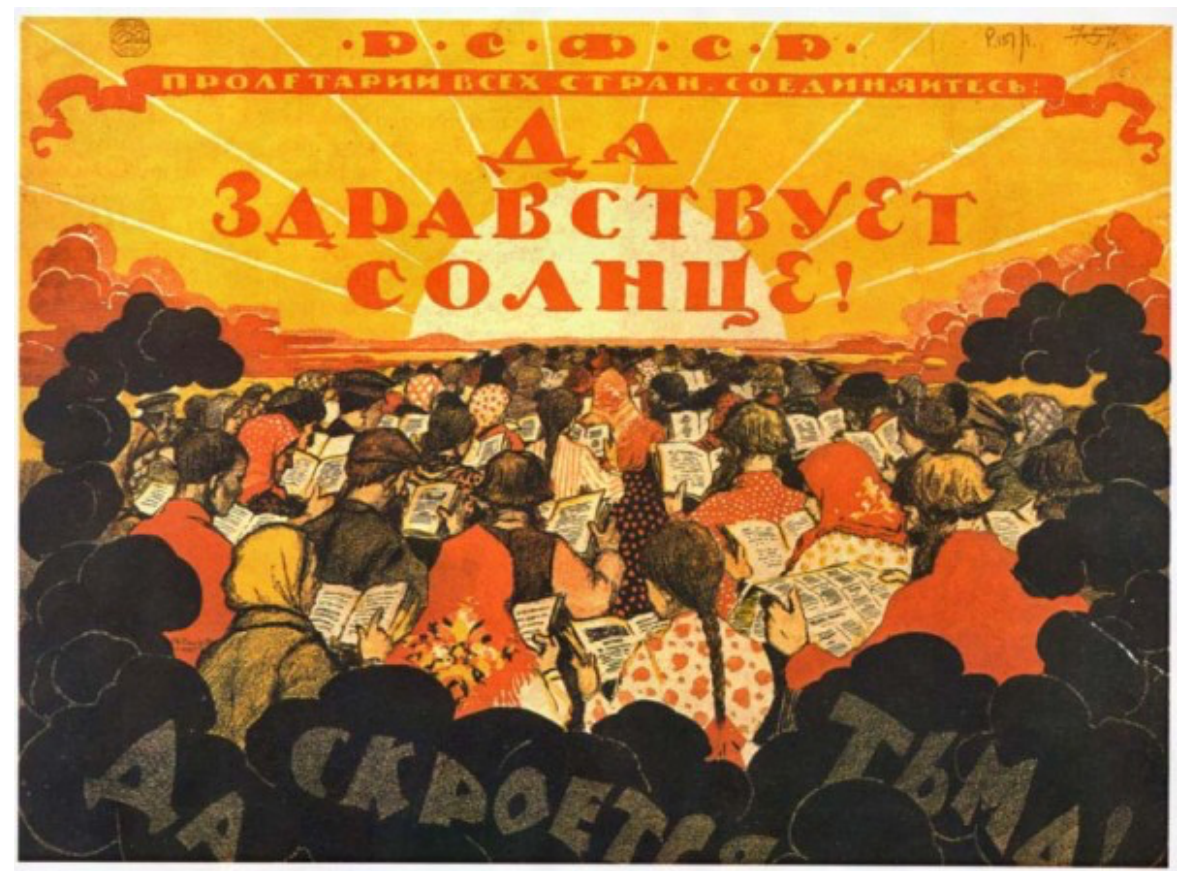

Figure 3. Long Live the Sun! May the Darkness Disappear! (Simakov, 1921).

The image of the sun is also a reference to the ideas of the 17-century enlightenment. The term enlightenment (prosveschenie in Russian) embraces a number of meanings. It is not only 'a European intellectual movement of the late 17th and 18th centuries emphasising reason and individualism rather than tradition' and 'the action of enlightening or the state of being enlightened' ('Enlightenment,' 2020), but also knowledge (Ozhegov \& Shvedova, 1997) and 'the dissemination of knowledge, education, and culture' (The Great Academic Dictionary of the Russian Language, n/d, p. 1343), as well as the system of education in general (e.g. the ministry of education was titled the 'Ministry of Enlightenment'). The representation of the rising or shining sun in some of the posters thus indicates the role of education and learning in constructing a new society and state full of the 'light' of new knowledge.

In Figure 4 below, a blind man on the left-hand poster represents peasants who had no relevant access to education but were also not motivated to learn. Without education, they had no control over their lives and were thus guided by others. In particular, as portrayed in another poster, peasants were guided by the Russian Orthodox Church and capitalists of all sorts (The Illiterate Man..., n.d.). The same poster cites Lenin's dictum on the importance of education to the Revolution: 'The illiterate man stands outside of politics. First, he must be taught the alphabet' (Unknown artist, n.d.).

The poster on the right of Figure 4 is an idealised version of a Reading House in the New World (large top panel), replacing a decadent rural past of wild drinking and socialising in pubs (bottom panel). In the mid 1920s, to unite various actors, means, and funds in organising vospitanie (education), prosveschenie (enlightenment) and obuchenie (teaching/learning) of peasants in their villages, the Reading House (izba-chital'nya) was created, and pronounced the political-enlightenment centre of rural adult learning and education activities (Twelfth Congress of the Communist Party, 1923/1968). Reading Houses were expected to provide inquiry office services, obuchenie for illiterate people, short-term vocational courses, reading circles, and newspaper readings. Soviet rural intelligentsia such as schoolteachers, agronomists and land surveyors, Party and komsomol (Soviet Youth Organisation) members, rural soviets, zhenotdels (women's departments at the Secretariat of the Central Committee and local party committees) and 
Trade Unions were expected to contribute to political-enlightenment activities at the Reading Houses. Despite many similarities with urban workers' clubs, reading houses were seen as centres of political prosveschenie and were warned off from turning into rural social or drinking clubs of the Old World, as pictured in the bottom poster panel.
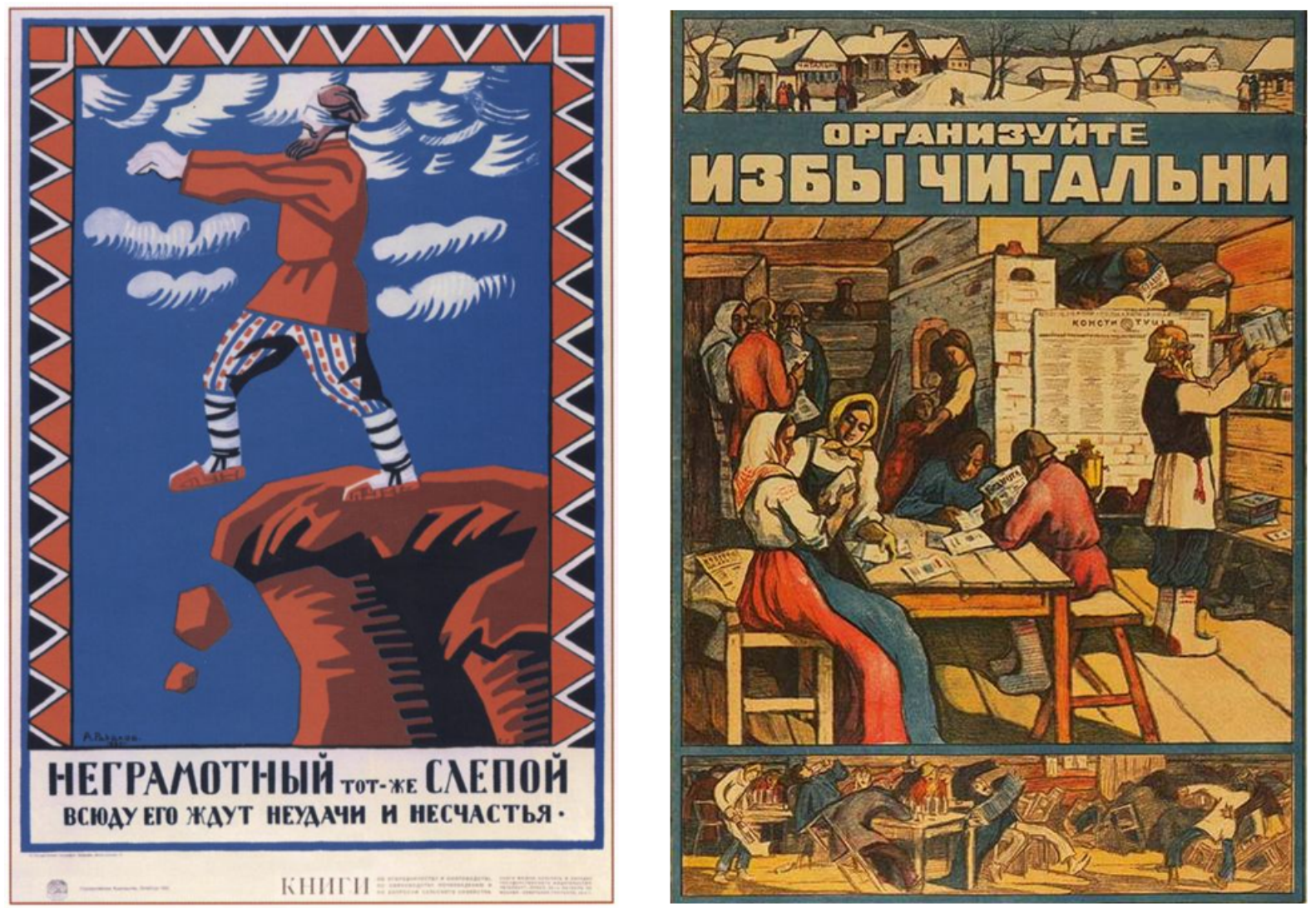

Figure 4. An Illiterate is a Blind Man: Failures and Misfortunes Await him Everywhere (left) (Radakov, 1920). Organise Reading Houses (right) (unknown artist, n.d.)

\section{Learning how to construct the new world}

Adult learners as critical to the creation of Socialist modernity. In the centre of the posters above are the Builders of socialism: foot soldiers, sailors, men and women peasants and workers representing the common people. In the Old World, they were deprived of a decent education, fair labour conditions, access to arts, and governance. By contrast, New World learners include people of all backgrounds: multiple posters proclaim that all human beings have the capacity to learn, regardless of age, gender, social status, or cultural background. One of the posters, for example, states, 'It is never too late to learn. School is open for everyone now. Welcome!' (Unknown artist, 1920a). In this same vein, the two posters below celebrate heroic women adult learners as workers and peasants (Figure 5). 


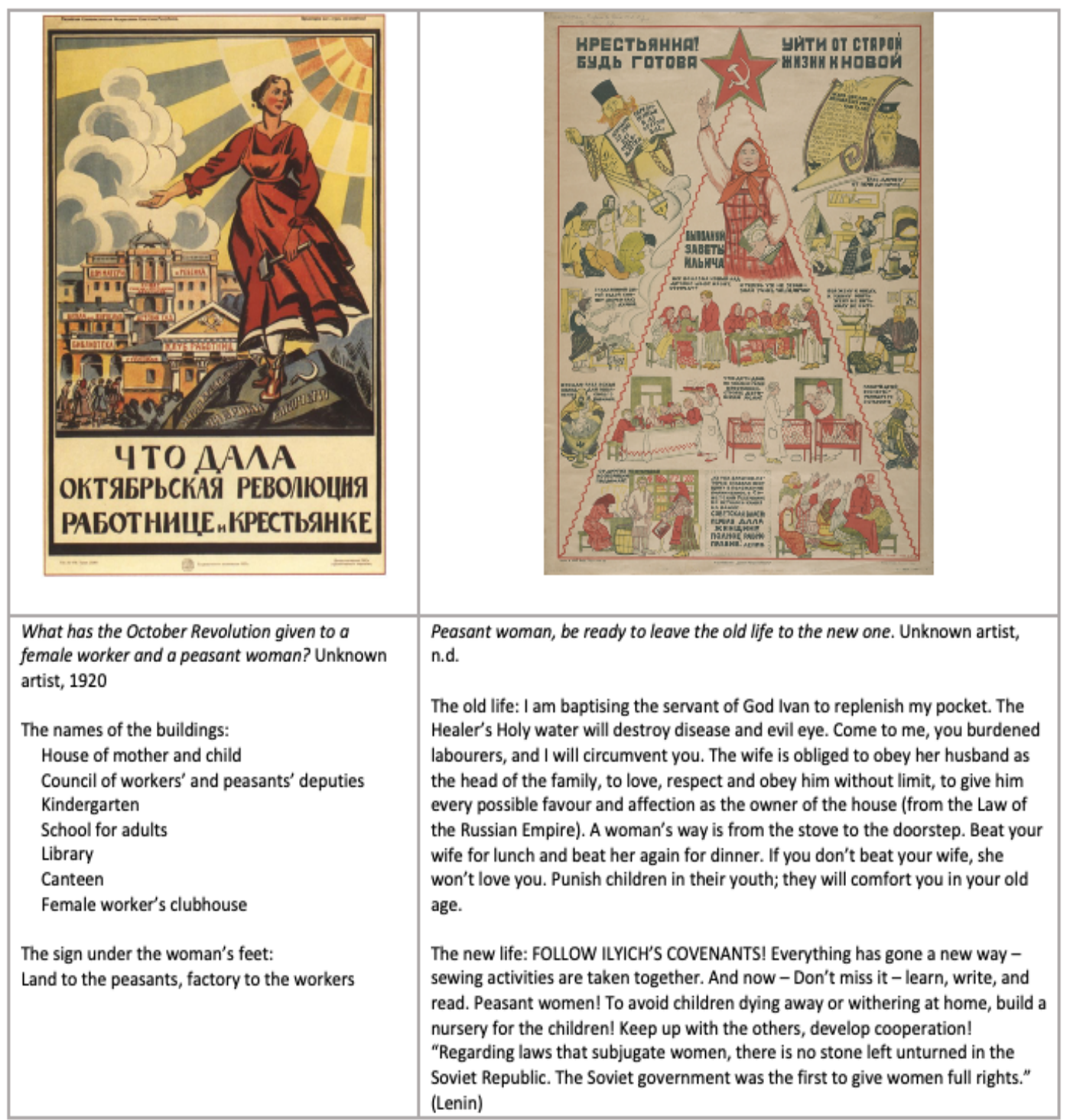

Figure 5. Posters Representing New Conditions of Life for Women Workers(left) and Women Peasants (right). (Unknown artists, 1920; n.d.)

In addition to foundational adult literacy associated with reading and writing skills, the new society demanded new types of life skills related to the construction of new norms and practices in the new Soviet learning society. Analysis of posters revealed several types of new socialist life skills: literacy for women's liberation, socio-political literacy, socio-economic literacy, and cultural literacy.

Literacy for women's liberation. The newly established Soviet state recognised women as having political power and being a very significant labour force. Various posters showed women being encouraged to emancipate themselves, to join the ranks of the working people and engage in the governing of the new society through their participation in the work of the soviets and in labour collectives (Lekht, 1921; Arshinov, 1923; 'Peasant woman...,' n/d). The construction of new social practices with women's active participation required teaching women labourers new life norms and behavioural patterns. One of the posters, for example, made the appeal to women: 'Enhance your literacy and culture, advance your qualifications, and change the practices of your everyday life' (Glan-Globus, n/d). Although addressed to women, literacy for women's liberation was equally about educating men, who were introduced to new attitudes, values 
and power dynamics between genders, and new standards in the family as a union of two equal persons.

Women's emancipatory literacy included new family, parenting and 'homerunning' literacy, replacing old oppressive gender roles, relations, and practices with new collective, liberating ways of organising women's lives. With nurseries, cooperation and new rights, women would free themselves from the burdens of patriarchy, drudgery of housework and sole responsibility of managing children; they could now work together collectively, and with more free time, participate in socio-political activities and in adult learning and education (Figure 5, above). To this end, the new state established a number of institutions to support women's emancipation from household duties and significantly reduce the burden of childcare and home choices, including Houses of Mother and Child, nurseries and kindergartens, laundry services, and canteens. As one poster proclaimed, 'Building nurseries, kindergartens and children's homes, women delegates remove the chains from the working mother. By building public canteens and fighting the devastation, working women will eventually win the liberation from domestic bondage' (Lecht, 1921). Parenting literacy included knowledge on the importance of educating children; for example, one poster advised, 'instead of scolding and beating children, it is better to buy them a book' (Pomanskyi, 1928). Women's health literacy was also addressed in part as freeing of women from burdens of pregnancy, motherhood, and childcare. These types of liberatory women's literacy education could hardly be delivered through formal schooling, and were instead studied in women's meetings, women's competitions, women's clubs and in their day-to-day work in labour collectives.

Socio-political literacy. With the change of social and political roles in the state, political knowledge became essential for both women and men. Being 'politically literate,' as portrayed in one poster (Lavinskyi, 1927), meant to be aware of the political programme of the state and to consciously participate in political life. This involved classrelated literacy that implied knowledge about deprived classes in a capitalist society, the claims of the working class(es), and their political agenda. Class-related knowledge had a significant practical value as class determined the major political powers that had state and party support. Belonging to the proletarian class also meant more possibilities in the newly established society. In other posters, a second avenue of political literacy involved knowledge about the system of power allocation in the new society, the work of soviets, and the process of delegating authority to represent working collectives (Lekht, 1921). This knowledge included how to construct a fair state with the power of the workingclass and how to govern the workplace and the state. In perspective, every person, including 'every female cook [was expected] to learn to manage the state' (quoting Lenin, on the poster by Makarychev \& Raev, 1925).

Socio-economic literacy. The new society implied new socio-economic patterns and new employment relations that were impacted by several factors. First of all, the new society was a learning society of full-time employed labourers; working was an essential responsibility. This advanced the fact of individual employment from a personal matter to a socio-economic matter and enhanced the weight of individual contribution in collective outcomes. Second, with proletariat ownership of lands, institutions and infrastructure, management of workplaces implied worker's governance. The skills related to the collective management of factories and kolkhozes (collective farms) constituted part of socio-economic and political literacy. Third, under a system of collective responsibility for production, professional knowledge was considered to be an important input to collective management. As one poster noted, 'To possess more, one needs to produce more. To produce more, one needs to know more' (Zhelenskyi, 1920). 
Therefore, advancing in a profession was considered an individual contribution to the common cause of building socialism.

Cultural literacy. Increasing the cultural level of the population was at the heart of the socialist project. Basic academic literacy and reading was part of it. Other avenues of cultural literacy involved healthy lifestyle knowledge, and learning arts, music, and drama. The poster below, for example, invites workers to attend a workers' club to 'get a rest, knowledge and entertainment' (Figure 6). The central pictures present the club's activities: socialising over a meal, dancing, doing sports (figure of a man throwing a discus, and another man skiing), listening to the radio, playing musical instruments, reading, and playing checkers.

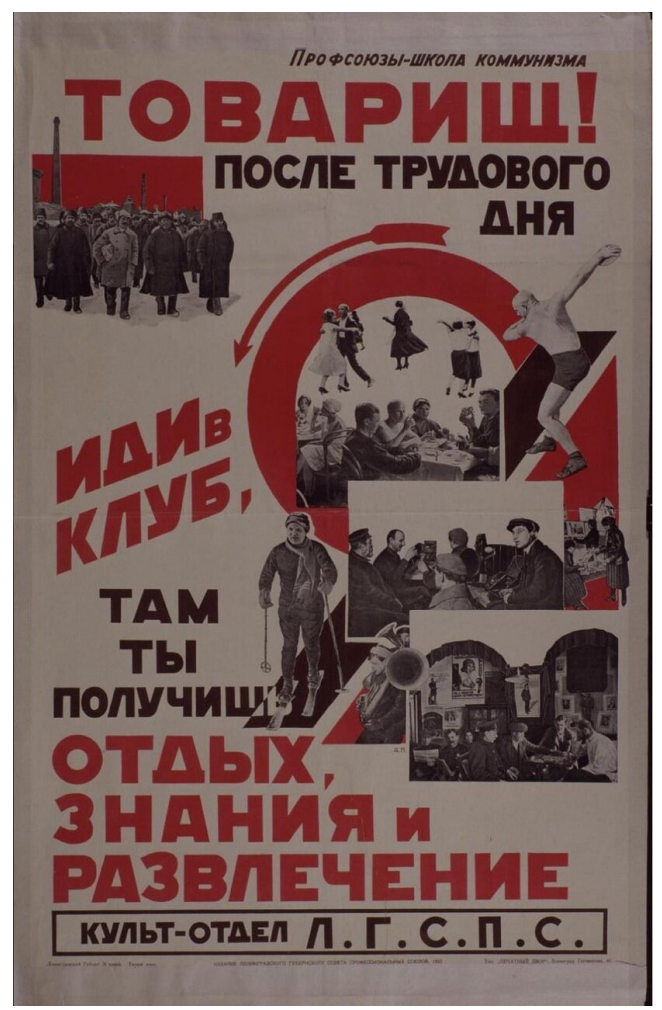

Figure 6. Comrade! After a Hard Day, Go to the Club, Where You Will Get Rest, Knowledge and Entertainment.

The posters also give an idea of how socio-political and socio-economic education was organised, picturing women's engagement in learning practices such as: reading at home (Isnar, 1920) and in a cooperative library (Arshinov, 1923), studying to read and write in a group of other women (Peasant woman, 1919-21), participating in a collective meeting and voting (Peasant woman, 1919-21; Lekht, 1921), participating in a demonstration (Lekht, 1921), and working as a delegate with the Workers' and Peasants' Soviet (Lekht, 1921).

\section{Spaces of learning}

The selected posters introduce four distinguishable groups of buildings/ learning spaces in the New World, associated with: 1) workspaces (factories, cooperative activities), 2) workers' clubhouses and rural reading houses, 3) 'traditional spaces' of knowledge production (academy), preservation and dissemination (libraries, schools, universities, 
palaces/houses of art); and 4) collective governance, collegial decision-making, and solidarity demonstration (Councils of workers' and peasants' deputies, street marches). Each of these spaces was constructed to be public, collective and distinct from the privatised Old World institutions of learning. All became spaces of learning in the new Soviet learning society.

Under the Russian Empire before the October Revolution, the family, church, and schooling system were the traditional providers of learning and education. With the establishment of anti-religious and pro-scientific discourse in the new Soviet state, the church as an institution of 'alternative' knowledge production was discredited. Private spaces of learning, such as the family, were subjected to reconstruction with the compulsory employment of women, the majority of whom used to provide full-time childcare and housekeeping, as noted in posters about women's emancipation above. The development of all types of new literacies and life skills shifted to the workshops of manufacturing plants, to factories and other workplaces, into the Councils of workers' and peasants' deputies, workers' clubhouses, libraries, schools for adults, and on-thestreet learning (e.g., solidarity demonstrations and marches, placard and poster-making).

Political gatherings at the workplaces and the work of village/district/city soviets. These became an essential school of new life and the space for developing sociopolitical and socio-economic literacies and advanced political knowledge. Besides professional activities, every labour collective organised regular meetings to discuss the socio-political agenda, express solidarity with the party-state decisions, assess the behaviour of its members, and elect delegates to represent the collective in soviets and councils at various levels. For example, one poster read, 'Women workers and peasants! Vote for the most dedicated to the working class and all workers individuals. At delegate meetings, they will shape you into resistant and conscious defenders. At delegate meetings, women workers and peasant women learn to understand and build their lives' (Lekht, 1921). Labour collectives became educative units of the Soviet learning society which provided up-to-date socio-political and socio-economic knowledge, and, through regular assessment of behaviour, allowed control over individual socio-political and socio-economic outcomes. At each level, socialist democracy of labour collectives, and local, regional and state soviets offered learning practices to develop socio-political and socio-economic knowledge and leadership skills.

Promoting and establishing reading practices. Many of the posters introduce reading as a new type of mass social practice which was highly promoted in the 1920s. The Book is one of the symbols frequently used in the posters. On every poster it holds some practical value; for example, early posters present reading as a valuable practice that leads to women's and class emancipation (Radakov, 1920). Books are the instrument to happiness (Kogout, 1921) and stimulate the growth of agricultural productivity (Zhelenskyi, 1920). Reading supports the defeat of enemies of the working class (Ivanov, 1920). Among the book titles on the posters are textbooks for professional use (geology, farming, economy, physics, mechanics, and aeronautics), books broadly associated with liberal arts and cultural heritage (history, philosophy, literature, art, belle-lettres) and personal interests (e.g., kitchen-gardens). Another means of organising reading practices was newspapers. Being the tribune of the party-state, newspapers were providers of the party-state knowledge. Self-guided learning through reading was promoted and supported by labour collectives and in institutions of education as well as by well-supplied libraries in every village and town.

On-the-street learning. Demonstrations and marches, broadly used in other types of states to fight with the system, became part of educative system in the USSR as space of mass declaration and the manifestation of socialist morality, values, and attitudes. For 
example, joining public demonstrations in solidarity with women labourers, as some posters expressed, was part of learning women's emancipatory literacy in the 1920s (Lecht, 1921; Valerianov, 1925).

\section{Knowledge construction and dissemination}

'Knowledge - to all!,' declares one of the posters (Unknown artist, 1920b). What knowledge was selected as the foundation of the new learning society?

Socio-political knowledge constructed by the party-state. The party-state became the primary producer of socio-political and socio-economic knowledge in the form of numerous documents, speeches and directives channelled primarily via newspapers and oral propaganda. In addition to materials printed for institutions of adult learning, newspapers became the guiding means for both self-education and studying in labour collectives. Besides the printed word, each collective had party-state knowledge holders, party and komsomol (youth organisation) members, who guided the production and assimilation of knowledge, as well as took a leading role in constructing practices of assessment of the acquired knowledge (approval, awards, admission to the party, censure, condemnation, appearance in the tovarishcheskiy sud or comrade court). The party-state used the printed and spoken word, and visual art to communicate knowledge, attitudes, and values in order to fill gaps in the socio-economic and socio-political literacy of the population.

Science. A scientific worldview was aimed at replacing religion. Science was declared as giving a clear and objective explanation of the material world as opposed to religious and superstition-based views. Science was also seen, in some posters, as a tool for enhancing production and productivity (Zhelenskyi, 1920). The union of science and labour was believed to support industrialisation and therefore, build a new modernity, as other posters indicated (Ivanov, 1920). Since science was seen to produce 'true' knowledge of the world, there were many efforts to interpret and frame Marxism and communism as a new social science. Scientific knowledge was considered a part of professional knowledge and taught starting early in middle school.

Morals. Besides the construction and interpretation of a worldview, the church also fulfilled an essential role in establishing moral guidelines for inner behaviour and ethics for interactions with others. This gap could not be completed by science or party philosophy alone. One of the new establishments of the new socialist learning society was thus the construction of a socialist morality. By comparing pictures of old and new life, the many posters above constructed knowledge of what is right and what is wrong. The tsar, religion, mysticism, exploitation, slavery, imperialism, capital and capitalists, idleness, ignorance, illiteracy, violence against women and children, and 'full-time housekeeping' were among the rejected values of the old life. Industrialisation, collective governing through soviets, labour, and labour collectives, bread, science, arts, education, literacy, books, knowledge, school, library, kindergartens, canteens, workers' clubhouses, women's equal rights, being socially and politically active, and advocating for the working class were among the values of the new socialist learning society. They comprise a new Soviet morality.

Arts. The production and distribution of knowledge occurred via literature, visual arts and performative arts, all generally referred to as producing cultural knowledge. This included new socialist literature and arts, as well as a selection of pre-revolutionary writers, poets, and artists who supported the working class through their artistic creations. As mentioned above, political posters were one of the ways of communicating socio- 
political messages. Arts were considered part of cultural knowledge and were taught starting early in elementary school. Cultural knowledge was further disseminated through 'cultural-enlightening' activities of workers' clubhouses, proletarian theatre, cinema, and libraries (Ignatovich, 2018).

\section{Educators and knowledge disseminators}

One of the most prominent authorities among party-state knowledge holders represented on the posters of 1917-1928 was Lenin, whose words were quoted multiple times. He was also mentioned on posters as 'Ilyich and his covenants' (Lenin's real name was Vladimir Ilyich Ulyanov). Portraits of both Lenin and Marx are also central to some of the posters. One of the early posters introduces a Communist Party member in the role of a Propagandist - an educator channelling party knowledge among the masses. On the poster is a man of exaggerated size, tossing books out to the masses to catch: 'Knowledge to all!,' states the poster (Figure 7).

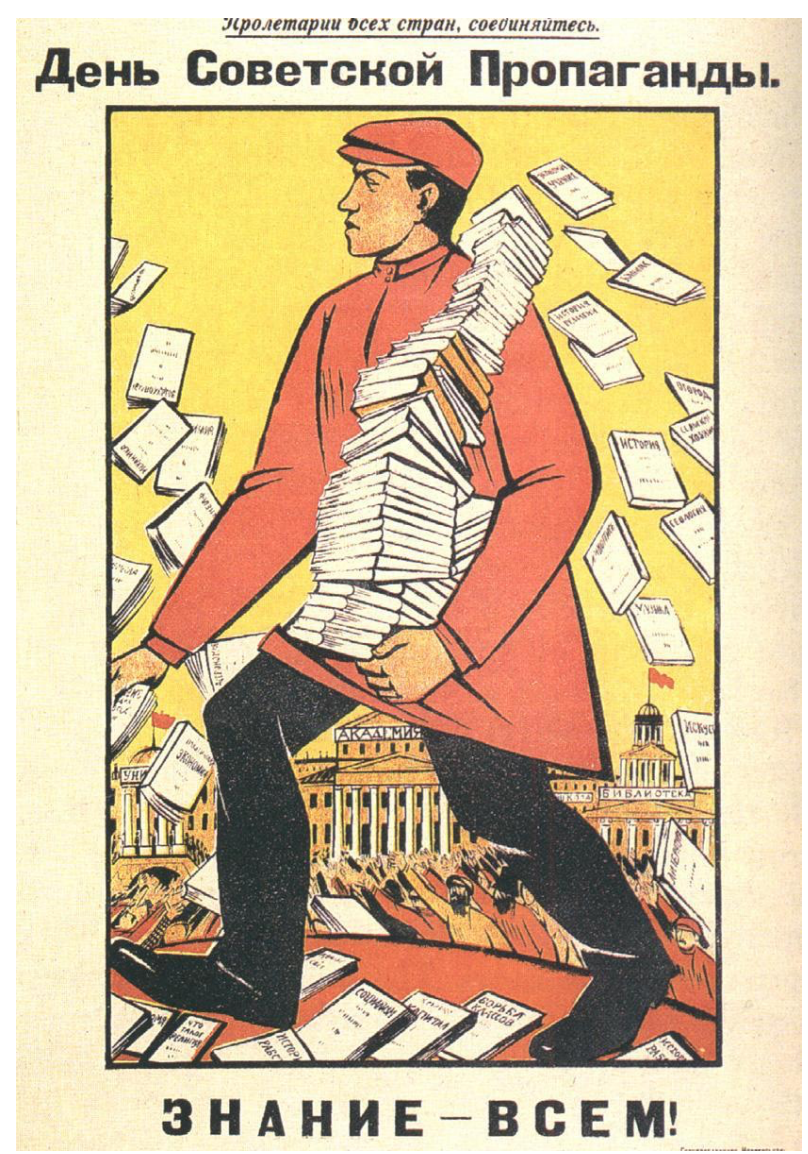

Figure 7. The Day of Soviet Propaganda. Knowledge - to All! Unknown artist, 1920.

Among other educators depicted on the posters is a Red Army soldier (Kogout, 1921), and a man in a black suit giving a speech to the masses from a raised dais (Ivanov, 1920). The position of the speakers suggests that they are the holders of relevant socio-political knowledge 'that will destroy the chains of exploitation,' as another poster states (Radakov, 1920). Both speakers point to a colossal size book behind them. The book indicates that the knowledge that they refer to is significant and bigger than just one 
presenter. The size of the book aims at convincing us that it can be a weapon against enemies and a tool in building a new life (Kogout, 1921). Posters addressing women's liberation present the 'new woman' educating other women to construct a new reality (Unknown artist, 1920c). They illustrate the possibilities for women liberation's (Isnar, 1920), and women teaching other women how to govern (Lekht, 1921).

One of the posters sends out a call to join the 'Down with illiteracy' society to help reach Lenin's goal of a fully literate society by the 10th anniversary of revolution (Unknown artist, 1925). The poster suggests that the population is divided into two groups: literate and illiterate; the former is called upon to support the latter by teaching to them to read and write. The poster refers to an all-USSR literacy campaign aimed at combating illiteracy among workers and the rural population.

Self-education is also highly promoted on the posters. They depict numerous women and men proletariat reading in various settings: in the daylight in front of a school building (Unknown artist, 1920a), a hand and a farm sickle on an opened book (Zhelenskyi, 1920), under the light of a lamp stand at night (Isnar, 1920), and in the library during the day (Arshinov, 1923; Unknown artist, 1923). Books are the main source of self-education depicted on the posters.

\section{Discussion}

The findings of our analysis of early Soviet era posters positioned within historical context of the time, 1917 to 1928 , demonstrate the many dimensions in the construction and implementation of a revolutionary Soviet learning society and educative state. As we show, learning societies and the notions of modernity which support them need not be confined to capitalist states, but following the notion of multiple modernities (Arnason, 2010; Eisenstadt, 2000), may take multiple forms under different state constructions. The posters analysed indicate that the newly born Soviet state aimed at creating a new socialist modernity implying the following:

- establishing new ways of ruling the state, including collective gatherings and the soviets

- making labour the central and compulsory activity that brings new society together with the production labour on the top

- prioritising scientific, Marxist and party-state knowledge over other types of knowledge as the basis for the social, political, economic, and cultural construction

- equalising men's and women's rights as the basis for developing new relations in the family, social sphere, and national economy

- constructing a new socialist morality based on the interests and needs of the proletariat and people of labour.

These aims suggest that most of social practices in the new society needed to be reconstructed; therefore, they became niches for adult education and learning. The aim of the enlightenment of the population and the development of their literacies came to the forefront. Besides basic academic literacy associated with reading skills, the population needed a new set of social knowledge and skills to navigate a new society and consciously participate in governing it. New Soviet citizens needed professional skills to function as part of a new national economy, and cultural skills to join in creating a new socialist culture. 
In a dynamically changing society with clearly articulated goals of creating a new Soviet socialist society, adult learning was integrated with the construction of new practices organised as out-of-school education. In many cases, it was difficult to disassociate learning from other social practices. The holders of relevant knowledge, e.g., reading and writing skills, socio-political, cultural, and professional knowledge, were expected to teach. These teaching functions could be performed in a schooling setting, but also at meetings, during collective activities, political functions like the election of collective representatives, the work of soviets, and in other new spaces of learning. New Soviet citizens were encouraged and expected to engage in self-education, again in a variety of learning settings, in a variety of ways. As such, the state was preparing every citizen to eventually perform both the role of a learner and the role of an educator. That is, in the Soviet learning society, everyone would be teaching and learning from everyone else. Besides providing the means of learning (e.g., books, newspapers, study circles), the Soviet state strove to provide infrastructure, (e.g., libraries, workers' clubs and reading houses), and secure time for learning for adults, and in particular, women, by opening canteens, laundries, and kindergartens, thereby liberating its citizens from household labour and the constant duties of child raising. Forms of resistance and solidarity used by citizens in other types of states to fight against the system (e.g., protests, marches, political demonstrations) became a legitimate part of the first decade of the Soviet state educative system for adults.

Along with the development a new state and the establishment of new practices, the purposes of adult learning and education included not just basic literacy and sociopolitical knowledge, but also the learning of cultural knowledge, such as performative arts, music, and sports activities. As the posters suggest, the idealistic idea behind 'knowledge to all' was to empower workers, soldiers, and peasants by means of enlightenment, learning and education to gain a clear vision of the world and their ability to rebuild it. In reality, however, literacy campaigns and promotion of compulsory reading practices had every literate citizen promoting a single, unifying socio-political party-state discourse. The primary goal of this effort was to synchronise the ways to interpret new knowledge in order to disallow multiple or dissenting readings. Thus, a massive collective sharing of Soviet socialist values and attitudes would lead to a homogeneous learning society with synchronised teachers, learning practices, materials, and spaces of learning.

\section{Conclusion}

In the history of the Soviet Union, the period of 1917-1928 was a time of massive, statemobilised adult learning and education embedded in the construction of a new state, new social practices, and a new society. This period and the learning society it created can be called a new Soviet Enlightenment. Yet because all learning practices were organised under the control and supervision of the party-state, the learning society was not shaped as a free, popular space of adult learning and education, neither as part of a social movement to reform the state, nor as a means of generating human capital for a capitalist economy. Instead, as our analysis of the Soviet posters demonstrates, the learning society was used to build a New World; a new collective state, with a population liberated from the ideology, material oppression and social confinements of the Old World of prerevolutionary Russia. The posters show that mass adult learning and education intended not only to educate the population about the goals of the state, its vision of 'reality,' and the knowledge they needed to achieve a new socialist society, but also to motivate citizens 
to engage with the messages, to adopt new forms of learning and teaching, and to instil in the Soviet people a sense of responsibility, accountability and inclusion as co-creators of the new Soviet learning society.

\section{References}

Anderson, K. T., \& Holloway, J. (2018). Discourse analysis as theory, method, and epistemology in studies of education policy. Journal of Education Policy, 12, 1-34. doi:10.1080/02680939.2018.1552992

Arnason, J. (2010). The cultural turn and the civilizational approach. European Journal of Social Theory, 13(1), 67-82.

Bashqawi, A. (2019). The Circassian miracle: The nation neither tsars, nor commissars, nor Russia could stop. Xlibris Corporation.

Bonnell, V. (1999). Iconography of power: Soviet political posters under Lenin and Stalin (Vol. 27). University of California Press.

Brickman, W., \& Zepper, J. (1992). Russian and Soviet education, 1731-1989: A multilingual annotated bibliography. Garland.

Central Statistical Office under the Council of Ministers of the USSR (1956). Narodnoe hozjajstvo SSSR. Statisticheskiy sbornik (In Russian). [The national economy of the USSR. Statistical compendium]. Retrieved from http://istmat.info/files/uploads/17165/ narhoz_sssr_1956_kultura.pdf

Coffield, F. (2000). Introduction: A critical analysis of the concept of learning society. In Differing vision of a Learning Society. Research findings (Vol. 1, pp.1-38). Policy Press.

Danilova, Y., \& Nurieva, N. (2015). Sovetskie plakaty kak sredstvo vizual'no-verbal'noj politicheskoj agitacii (In Russian). [Soviet posters as a means of visual and verbal political propaganda]. Mir nauki, kutury i obrazovaniya. Vol 2(51), p. 408-411.

Dobrenko, V. (2009). The image of the enemy: The Evolution of the 'other' in Bolshevik political posters from the October Revolution and the Civil War. Revue Belge de Philologie et d'Histoire, 87(3), 685-704.

Dosekin, E. (2015). Sovetskij politicheskij plakat v sisteme kommunikacii vlasti i obshhestva (In Russian). [The Soviet political poster in the system of communication between the government and society]. E. Semenova (Ed.). Chelovek i obshhestvo v uslovijah vojn i revoljucij: Conference proceedings. Samara State University.

Eisenstadt, S. (2000). The civilizational dimension in sociological analysis. Thesis Eleven, 62(1), 1-21.

Eklof, B. (2008). Russian literacy campaigns 1861-1939. In R. F. Arnove, H. J. Graff (Eds.), National literacy campaigns and movements: Historical and comparative perspectives, (1st ed.). Routledge, (pp. 123-145). doi:10.4324/9781315125077-6

English, L. M., \& Mayo, P. (2021). Paulo Freire and the Debate in Lifelong Learning. In Lifelong Learning, Global Social Justice, and Sustainability (pp. 75-92). Palgrave Macmillan, Cham.

Enlightenment. (2020). In Oxford Online Dictionary. Retrieved November 30, 2020, https://www.lexico.com/definition/enlightenment

Fitzpatrick, S. (1970). The Commissariat of Enlightenment. Soviet Organisation of Education and the Arts under Lunacharsky, October 1917-1921. London.

Fitzpatrick, S. (1979). Education and social mobility in the Soviet Union, 1921-1934. Cambridge University Press. doi:10.1017/CBO9780511523595

Foucault, M. (1977). Discipline and punish (A. Sheridan, trans.). Pantheon.

Foucault, M. (1978). The history of sexuality (1st American ed.). Pantheon Books.

Foucault, M. (1980). Power/Knowledge: selected interviews and other writings 1972-1979. Pantheon.

Ginsberg, M. (2013). The Art of Influence: Asian Propaganda. Hotei Publishing.

Habermas, J. (1962/1991). The structural transformation of the public sphere. MITPress.

Hake, B., Glastra, F., \& Schedler, P. (2004). Workers as travellers, migrants, and refugees: Bordercrossings and the construction of proletarian public spheres in Europe before the Second World War. In B. J. Hake, B. van Gent, \& J. Katus (2004). Adult Education and Globalisation: Past and Present. Peter Lang.

Harcave, S. (1970). The Russian revolution of 1905. Collier-Macmillan.

Ignatovich, E. (2018). Ot vneshkol'nogo obrazovanija k dopolnitel'nomu: sravnitel'nyj istorikolingvisticheskij analiz konceptov [From "out-of-school education" to "supplementary education" 
in Russia: a comparative historical-linguistic analysis of the concepts (the 18th - 21st centuries)]. Lifelong Education: The Twenty-First Century, 3(23), 2-26. doi: 10.15393/j5.art.2018.4024

Jarvis, P. (2007). Globalisation, lifelong learning and the learning society: Sociological perspectives. Routledge. https://doi.org/10.4324/9780203964408

Livingstone, D. W., \& Guile, D. (2012). The knowledge economy and lifelong learning: A critical reader. BRILL

Kahan, A. (1989). Russian economic history: the nineteenth century. University of Chicago Press.

Kenez, P. (1985). The birth of the propaganda state: Soviet methods of mass mobilization, 1917-1929. Cambridge University Press.

Mironov, B. (2010). Blagosostoyanie naselenia i revoliutsii v imperskoi Rossii (In Russian). [The Welfare of the Population and the revolutions in the Russian Empire]. Novyi Khronograf.

Nicoll, K. (2006). Flexibility and lifelong learning: Policy, discourse, and politics. Routledge.

Oushakine, S. (2016). Translating communism for children: fables and posters of the revolution. Boundary 2, 43(3), 159-219.

Ozhegov, S., \& Shvedova, N. (1997). The explanatory dictionary of the Russian language. Retrieved from http://ozhegov.info/

Polonsky, V. (1925). Russkij revoljucionnyj plakat (In Russian). [Russian revolutionary poster]. State Press.

Rose, G. (2016). Visual methodologies: An introduction to researching with visual materials (4th ed.). Sage Publications.

Roselle, L. (2017). Communist posters. Middletown: American Library Association CHOICE.

Salter, P. (2014). Knowing Asia: Creative policy translation in an Australian school setting. Journal of Education Policy, 29(2), 145-164. https://doi.org/10.1080/02680939.2013.794303

Schugurensky, D. (2007). The learning society in Canada and the US. In M. Kuhn (Ed.), New Society Models for a New Millennium. The learning society in Europe and beyond (pp. 295-334). Peter Lang.

Starks, T. (2017). Propagandizing the healthy, Bolshevik life in the early USSR. American journal of public health, 107(11), 1718-1724.

Stevick, E. D. (2010). Education policy as normative discourse and negotiated meanings: Engaging the holocaust in Estonia. Prospects, 40(2), 239-256. https://doi.org/10.1007/s11125-010-9158-2

Stewart, T. T. (2012). English teachers, administrators, and dialogue: Transcending the asymmetry of power in the discourse of educational policy. English Education, 44(4), 375-393.

The Great Academic Dictionary of the Russian Language (n/d). Vol. 11. Retrieved from https://www.academia.edu

Tolstikova, N. (2007). Early Soviet Advertising: 'We Have to Extract All the Stinking Bourgeois Elements.' Journalism History, 33(1), 42-50.

Twelfth Congress of the Communist Party (1923/1968). Verbatim report, Moscow.

Waldron, P. (1997). The End of Imperial Russia, 1855-1917. Reader in History University of Sunderland. Palgrave: Macmillan.

White, S. (1988). The Bolshevik Poster. Yale University Press.

Williams, C. (2012). 'Let's Smash It!' Mobilizing the Masses against the Demon Drink in Soviet-Era Health Posters. Visual Resources, 28(4), 355-375. 